\title{
ECONOMIC LIBERALISATION OF EDUCATION PROVISION WITHIN THE EC \& WTO: A HUMAN RIGHTS PERSPECTIVE
}

\begin{abstract}
John Morijn*
Summary: This paper addresses the impact of WTO- and EC-driven liberalisation of trade in services on non-trade policies. Adopting a human rights perspective, which is given as having a critical bearing on both "trade" and "non-trade" in "trade and ..." discussions, it seeks particularly to map an analysis of the merits of (further) subjecting education provision to economic liberalisation. As concerns the WTO, assessment of the GATS' wording leads to the finding that education provision seems likely to be construed as within GATS' scope, and therefore fully subject to its disciplines. In that context, it is submitted that states' decisions concerning offering (and seeking) commitments in the area of education provision need to be informed by human rights obligations, such as that of provision "free of charge". In the EC context, distinction is made of the internal and external component of education-as-service discussions. Internally, the Court of Justice has excluded education provision from the legal discipline of the free movement of services, a situation seemingly increasingly at odds with the far-reaching subjection of the provision of similar public goods, such as health care. Yet, due to education's specific nature in forming individuals and societies, it is argued that there are important reasons to keep excluding (parts of) education provision from the EC services law discipline. Externally, the concern relates in particular to the possibility that developing countries will be requested by the EC to provide EC-based economic operators access to their education 'markets' at a stage when it is not yet possible to determine whether the EC foreign policy objective of human rights advancement can be guaranteed.
\end{abstract}

\section{Introduction}

Policies designed to further non-trade issues embodying essential societal values are nowadays frequently simultaneously subject to multiple international and supranational trade liberalisation regimes. For the European Community (EC), this implies that developments influencing its trade and non-trade policy-making no longer originate solely in the EC legal order itself but also, for example, in the World Trade Organisa-

" Researcher, European University Institute Law Department, Florence, Italy. 
tion (WTO). As a result, the predictability and legitimacy of the European integration process has become conditional upon the careful assessment of developments outside of it. Issues of balancing trade and non-trade policy-making today require careful multilevel analysis.

This paper seeks to provide the beginning of a multilayered analysis of but one topical trade/non-trade issue that is debated in different forums: the impact of trade in services liberalisation on education provision. This subject is present, firstly, in the current legal provisions of the EC Treaty. It is also dealt with in a significantly different way under the provisions of the Constitutional Treaty (CT) now pending for ratification. Secondly, it is on the agenda of the current Doha Development Round of negotiations as conducted within the WTO. Even if the legal contexts are different, similar questions are raised in these interconnected settings. Therefore, studying in parallel how EC and WTO law provisions are to be understood as speaking to the interface of trade liberalisation and education policy is beneficial for appreciating likely future policy-directions and their implications.

To an EC legal specialist, the framing of the problem may appear odd at first sight. After all, it is well known that the European Court of Justice (ECJ) has held in its case law that the provision of national education, as long as it is largely financed from the public purse, is not a service and therefore not subject to the EC legal discipline of free movement of services. ${ }^{1}$ Yet, quite clearly at odds with this, the currently dormant EC common commercial policy provisions lay down the possibility of making a commitment to liberalising the national education provision of the Member States as a "service" under the WTO's General Agreement on Trade in Services (GATS). ${ }^{2}$ In addition, the CT once again changes the picture of the economic liberalisation/education policy nexus, and in a way that is not immediately transparent. On the one hand, the wording that only a "risk of seriously disturbing the national organisation of education services" will justify unanimity voting ${ }^{3}$ can be taken as signifying a strong political determination to consider some form of future EC ac-

\footnotetext{
${ }^{1}$ Case C-263/86 Belgian State v Humbel [1988] ECR 5365 paras 17-19; case 109/92 Stephan Max Wirth $v$ Landeshauptstadt Hannover [1993] ECR I-6447 paras 15-17.

${ }^{2}$ Art 133(6), para 2 EC: "Agreements relating to ... educational services ... shall fall within the shared competence of the Community and its Member States. [I]n addition to a Community decision taken in accordance with ... Article $300 \mathrm{EC}$, the negotiation of such agreement shall require the common accord of the Member States."

${ }^{3}$ Art III-315(4) para 3, under (b) CT: "The Council shall ... act unanimously for the negotiation and conclusion of agreements ... in the field of trade in ... education ... services, where these agreements risk seriously disturbing the national organisation of such services and prejudicing the responsibility of Member States to deliver them" (emphasis added). The wording implies a fall-back to qualified majority voting (art III-315(4) para 1) if "seriously disturbing" is not established.
} 
tion on education services. On the other, the upgraded EU Fundamental Rights Charter (Charter) could come to serve as a counterbalancing force against overly economic (or any other form of single-minded) appreciation of multifaceted policy questions. ${ }^{4}$

WTO lawyers and liberal trade economists are likely equally to express surprise as to the choice of focus of the paper. For even if education is one of the 12 services areas in which states may opt to seek and offer commitments in the GATS context, commitments have so far in fact been few. Yet, there is no sector that is a priori excluded from the current round of trade negotiations. Given the mercantilist nature that such negotiations have always had, it is quite likely that requests are made with regard to one sector to compensate for a "sacrifice" in another. Sectors for which the implications of liberalisation have remained under-negotiated, and hence under-explored, are more vulnerable to being "negotiated away" in last minute deals. This alone justifies addressing the problem even at this stage.

The analysis is undertaken from the particular viewpoint of human rights law and principles. Both in the WTO and EC legal settings, human rights are legally relevant by virtue of their binding nature in parallel to the norms more primarily concerned with freeing and disciplining trade. This does not, however, mean that it is always immediately clear which human rights are likely to be strengthened or threatened in a particular context of economic liberalisation. It is not to be denied that the process of ongoing economic liberalisation also forces human rights proponents more clearly to articulate their concerns. In that light, the question is raised whether human rights norms dealing with education are sufficiently clear on the international and European level to help refine, and possibly redefine, the economic liberalisation/education provision discussion.

The discussion will be undertaken as follows. First, by way of background to the method of analysis, the meaning and function of a human rights perspective of trade liberalisation is clarified (section 2). Next, the nexus of liberalisation of services and education policy within the WTO/ GATS setting is discussed with particular reference to the human right to education (section 3). In the following section, the same exercise is undertaken for the EC context (section 4). We will end with a brief conclusion (section 5).

\footnotetext{
${ }^{4}$ See for some suggestions on the possible transformative impact of the EU Charter on legal rules and methodologies of economic integration, J Morijn, 'Balancing Fundamental Rights and Common Market Freedoms in Union Law: Schmidberger and Omega in the Light of the European Constitution' (2006) 12(1) European Law Journal 15.
} 


\section{The meaning and function of a human rights perspective of trade liberalisation}

Discussions of the merits of trade liberalisation generally, and the implications of specific areas of trade liberalisation on societal values and human rights protection, are typically polarised. Rare is the observer from the trade, non-trade or human rights discipline who is not only truly versed in the nuts and bolts of the "others"' law ${ }^{5}$ but also explicitly tries to come to an even-handed analysis. As a well-known trade lawyer recently wrote: "the division between trade and human rights is often exacerbated by the approach in the literature...both sides have perhaps displayed an air of advocacy". ${ }^{6}$ Therefore, by way of background, it is necessary to clarify how trade liberalisation typically impacts on non-trade policies and what a human rights perspective could add to this debate.

One of the reasons for the limited understanding between traders and proponents of any non-trade issue generally is that it is frequently not well articulated or explicated by either side just how their disciplines are perceived as coming to interrelate. It is far from straightforward. Therefore, it may be useful here to present a simplified articulation of the aspects of the interplay between trade liberalisation and non-trade issues that are of particularly significance to tracking the human rights dimension.

The basic idea of an economic integration scheme is that States member to it gradually merge (chosen parts of) their national markets into one. The resulting freer circulation of companies, capital and products contributes to the discovery and survival of the most efficient rules, since economic agents tend to move to where the regulatory environment is more favourable to their objectives. ${ }^{7}$ As a consequence, standards of national regulation themselves (such as education policy) will also be competing in the international market, ${ }^{8}$ which generates a process of regulatory competition among states.

\footnotetext{
${ }^{5} \mathrm{C}$ McCrudden, 'International Economic Law and the Pursuit of Human Rights: A Framework for Discussion of "Selective Purchasing" Laws under the WTO Government Procurement Agreement' (1999) 3 JIEL 47: "One of the difficulties conducting [the] debate [of international economic law and the pursuit of human rights] is the existence ... of largely separate spheres that those concerned with international trade, on the one hand, and human rights, on the other, seem to inhabit. Few are experts in both, and there is often considerable difficulty in developing a common language for discussion between them".

${ }^{6}$ JH Jackson, 'Reflections on the Possible Research Agenda for Exploring the Relationship between Human Right Norms and International Trade Rules', in FM Abbott et al. (eds), International Trade and Human Rights,Ffoundations and Conceptual Issues (University of Michigan Press, Ann Arbor 2005 (forthcoming)).

7 E-U Petersmann, 'From "Negative" to "Positive" Integration in the WTO: Time For "Mainstreaming Human Rights” into WTO Law?' (2000) 37 CMLRev 1363, 1370.

${ }^{8}$ MP Maduro, 'Is There Any Such Thing As Free or Fair Trade? A Constitutional Analysis of the Impact of International Trade on the European Social Model' in G De Búrca and J Scott (eds), The EU and the WTO (Hart Publishing, Oxford 2001) 260.
} 
Regulatory competition, if and when it occurs, ${ }^{9}$ influences national policies (and therefore the individual entitlement aspects inherent in them) in a complex way. Although there is "no legal obligation on states to [adapt or] lower standards, economic competition [will] open [states'] regulatory systems to corresponding competition and efficiency criteria, which means a de facto subjection of normative ideals to economic competition". ${ }^{10}$ With a view to remaining sufficiently competitive in the area of potential comparative advantage, states may start thinking ${ }^{11}$ of measures to change their regulatory system (potentially in any field of national policy) in order to attract trade.

Reconsideration of national policies resulting from trade liberalisation has often been described in terms of leading to "a race to the bottom". Yet, it is important to have a clear understanding of what this entails. Most observers agree that no such thing occurs as a race literally to the bottom. ${ }^{12}$ The concern arises from the possibility that economic integration, and the way in which its rules are interpreted, will lead to a regulatory dynamic in which standards are set (and/or cherished), and measures taken (or postponed), strategically. That is, in order to estimate the relative impact of the reform measure on the competitive position, policy-making in any field is likely to come from the primordial viewpoint of trade economics.

The point to be made is that this may lead to disregard of the specific own logic and rationale of the non-trade policy-area, potentially resulting in solutions that are sub-optimal from the perspective of the non-trade policy. ${ }^{13}$ In other words, in the operation of the rules of economic integration aiming at increasing efficiency and wealth, states' non-trade regula-

\footnotetext{
${ }^{9}$ It has been argued that the concept of regulatory competition only takes place in highly specific regulatory contexts involving particular activities or products, but that it does not generalise well and hence may be of limited explanatory value; G Davies, The Legal Framework of Regulatory Competition' (2006) <http://papers.ssrn.com/sol3/papers. cfm?abstract_id=903138> (3) accessed 3 October 2006. This paper does not aim at engaging with that finding as such. Rather, the simplified description presented here is intended to illustrate the most obvious dynamic by which the operation of trade law (i.e. free movement of goods, services, etc.) can come indirectly to influence the sustenance and articulation of individual entitlements embedded in national regulation. In other words, a discussion of regulatory competition in the limited field of economic free movement law is introduced to set the stage for articulation of how human rights could be influenced (both positively and negatively) by trade liberalisation.

${ }^{10}$ Maduro (n 8) 263. Emphasis added.

11 This is not to say that it will always happen. As has been pointed out, "changing regulation may stimulate economic activity in one state without having a direct or correlative negative effect on activity in others... the model [of a process of competition between states] should not be understood in quite such a discrete way"; Cf. Davies (n 9) 5.

12 AT Guzman, 'Trade, Labor, Legitimacy' (2003) 885 California Law Review fn 28.

13 DC Esty, 'Bridging the Trade-Environment Divide' (2001) 15(3) Journal of Economic Perspectives 113, 124.
} 
tory powers are conditioned, potentially resulting in perversely affecting the running of (or honouring the international obligations inherent in) those policy areas. As a result, many issues, at first sight unrelated to free trade rules, may sometimes end up being subject to their disciplines, and their interpreters' logic.

This brings us to the question of the meaning and function of human rights law in this context of the impact of economic integration on non-trade policy-making. There is a need for an explicit treatise given the degree of suspicion about the reasons for voicing human rights concerns in a trade context. ${ }^{14}$ Even if the following is mainly focused on the WTO setting, it should be seen as directly relevant to the EC setting by virtue of the EC's WTO membership, and the resulting legal relevance of WTO law in the EC legal order.

A helpful starting-point is a number of policy papers produced by the Office of the High Commissioner for Human Rights (OHCHR) dealing with the impact of specific WTO trade rules on human rights. These reports ${ }^{15}$ articulate an approach to trade liberalisation that is explicitly based in human rights law and define a legal methodology to assess the relationship between trade and human rights. It is stated that the human rights approach to trade "sets as entitlements the basic needs necessary to lead a life in dignity and ensures their protection in the processes of economic liberalisation". ${ }^{16}$ These entitlements cannot be "reduced to mere privileges or luxuries or left subject to the whims of the market". ${ }^{17}$ Therefore, the notion that human rights are the universally applicable entitlements of every human being is the basis of their application to trade law.

The legitimacy of invoking human rights obligations is explained with reference to the fact that all WTO members have undertaken ob-

\footnotetext{
${ }_{14}$ As a recent fascinating paper has sharply put it: "[B]oth supporters and opponents of free trade are using human rights in their arguments for or against the liberalisation of trade ... yet the overuse of human rights language threatens to devalue the concept of human rights, reducing it to a catch-phrase employed by both sides of the discussion to convince the challenger of the legitimacy of their claims... this not only seems to blur the picture rather than clear it up, it also has negative effects on the concept of human rights"; Floris Van Hees, 'Protection v. Protectionism - The Use of Human Rights Arguments in the Debate for and against the Liberalisation of Trade' (2004) master thesis defended in the European Master's Programme in Human Rights and Democratisation <http://www.kenan-flagler.unc.edu/ assets/documents/hrtProtectionVersusProtectionism.pdf> (38) accessed 3 October 2006.

${ }^{15}$ See in particular the Office of the High Commissioner for Human Rights, 'The Impact of the Agreement on Trade-Related Aspects of Intellectual Property Rights on human rights' (2001) E/CN.4/Sub.2/2001/13 (TRIPS Report); Office of the High Commissioner for Human Rights, 'Globalisation and its impact on the full enjoyment of human rights' (2002) E/CN.4/2002/54 (AoA Report) (focusing specifically on the Agreement on Agriculture); and Office of the High Commissioner for Human Rights, 'Liberalisation of trade in services and human rights' (2002) E/CN.4/Sub.2/2002/9 (GATS Report).

${ }^{16}$ GATS Report para 6.

${ }_{17}$ GATS Report para 6; AoA Report para 9.
} 
ligations under human rights treaties and that in any context "human rights are the first responsibility of Governments". ${ }^{18}$ Of significance for the discussion to follow is that only two current WTO Members have not ratified the International Covenant on Economic, Social and Cultural Rights $^{19}$ and only one has not ratified the Convention on the Rights of the Child. ${ }^{20}$ Therefore, the overwhelming majority of WTO member states hold concurrent responsibilities to promote and protect social and economic rights, such as the right to education, as well as to implement trade rules. ${ }^{21}$ The reports argue that WTO members have human rights obligations at all stages of the process of trade liberalisation - when negotiating new agreements or revising existing ones, when implementing the rules that have already been negotiated, and also in monitoring the effects of the agreement they have entered into. ${ }^{22}$ In short, WTO Members are legally bound to promote and protect human rights when acting within the ambit of trade law. ${ }^{23}$

The focus of the OHCHR human rights approach to trade is on processes and outcomes - on how trade liberalisation efforts affect the enjoyment of human rights in actual fact. The fundamental argumentation is that even if the overall result of the liberalisation of a specific form of trade is wealth creation and welfare enhancement, and even if the increased resources trickle down to some extent to those most marginalised in each society, there will still be losers during and as a result of the process. To deal with that reality, a human rights approach provides a methodology for assessing when the "losers" from the process of trade liberalisation are bound to lose, or are unjustifiably prevented from benefiting, and when action is required.

Even if these reports provide a valuable starting-point, it is argued here that they naturally lead to a number of further findings that may

18 TRIPS Report para 13; AoA Report para 10.

19 The United States and South Africa, the latter country's situation being significantly mitigated from a human rights perspective by the presence of the world's most judicially activist Constitutional Court in the field of social human rights.

20 The United States of America.

${ }^{21}$ AoA Report para 8.

22 AoA Report para 8; GATS Report para 7.

${ }^{23}$ This paper does not discuss the problem of how human rights law can come to be brought up, and approached, as relevant, in WTO dispute settlement as a matter of WTO law. This in itself is far from an uncontroversial matter. It is presupposed here that, as a matter of legal coherence, human rights law must be relevant to WTO dispute settlement, particularly when brought up by States in defence of the human rights of their own population. The simple reason is that states cannot be presumed to have laid off their human rights obligations when entering an economic integration scheme. It is only a matter of time before a state phrases legal arguments in terms of human rights in a WTO dispute. For an analysis of the methodological issues arising from a state invoking human rights to make a challenge in the EC law context, see Morijn (n 4). 
benefit from clearer explication if the aim is to make human rights analysis relevant and operational, for example in the field of the economic liberalisation of education provision.

Raising human rights concerns in a trade context is typically dealt with as yet another non-trade challenge to trade liberalisation. Indeed, even if their own analysis logically leads elsewhere, OHCHR reports do not clearly attempt to explicate the contrary. It is here argued, however, that presenting human rights protection as a non-trade issue is substantively and functionally erroneous. I will deal with these aspects in turn.

Firstly, taking into account that international human rights law views the totality of economic, social, cultural, civil and political human rights as based on a unified legal rationale (without, however, denying the possibility of tension between different human rights), addressing human rights in a trade context cannot be seen as a non-trade concern like environmental protection or the safeguarding of cultural diversity. A human rights and non-trade policy may often coincide in pushing back the reverse effects of trade liberalisation, but this is not necessarily so. Human rights protection's bottom-up concern with the position of individuals makes it at heart qualitatively different from trade and non-trade policies' top-down preoccupation with limited sectoral societal concerns. Human rights law takes as its primary focus individuals as legal subjects, rather than itself constituting a policy objective. ${ }^{24}$

Secondly, seeing human rights protection as a non-trade topic is also functionally problematic. It tends solely to stress that states still have the possibility to regulate in a trade context, rather than that states are in fact required to act as a matter of human rights law both in trade and non-trade contexts. This point is of particular significance for the coming analysis. In the GATS context, the treatise of trade liberalisation's impact on non-trade policies often focuses on the question of the extent to which states maintain a measure of regulatory autonomy/policy space to pursue whatever other objectives they may want to pursue. It is then typically argued by trade analysts that GATS flexibility leaves states sufficient space to do as it pleases nationally.

\footnotetext{
${ }^{24}$ An article by the former Special Rapporteur on the Right to Education that critically addresses the intentions of some leading human rights NGOs that have recently broadened their professional focus to include economic, social and cultural rights (such as Human Rights Watch) implicitly holds this line of reasoning, K Tomasevski, 'Unasked Questions about Economic, Social and Cultural Rights from the Experience of the Special Rapporteur on the Right to Education (1998-2004): A Response to Kenneth Roth, Leonard S. Rubenstein, and Mary Robinson' (2005) 27 Human Rights Quarterly 709: “economic, social and cultural rights are not about poverty but policy" (713) and "those who claim to be doing human rights work should be distinguishable from their colleagues who work in education" (712).
} 
However, from the broader viewpoint of international law, one often cannot escape the impression that it is not appreciated that regulatory autonomy is not only circumscribed by WTO law, but in fact by many international obligations simultaneously, including human rights law. However difficult this may be, WTO (and EC) law scholars and interpreters cannot side step, or wish away, this reality. ${ }^{25}$ As a result, presenting trade agreements as very flexible (and therefore - it is clearly implied hardly capable of creating problems) can underplay the tension between the simultaneous international obligations flowing from WTO agreements, treaties dealing with non-trade matters and international human rights treaties which are all part of the system of international law. ${ }^{26}$

This is of course not a neutral observation, nor does it lead to easy or less contentious analysis. As Professor Jackson has written, "perhaps the most difficult aspect of the dialogue between trade and human rights is the task of looking at the future policy implications and issues ... in other words, what is the logic of the two subjects, and where does their combination lead?"27 It is obvious that different policy and legal angles are sometimes at odds, and interpretational choices will need to be made. For, as has been correctly observed, "tensions between trade and nontrade objectives and their possible solution lie at the heart of the emerging system of global economic governance". ${ }^{28}$

It is submitted in the context of the coming analysis that the purpose and effect of a human rights analysis is simultaneously to scrutinise and (re)direct trade and education policy in an attempt to give expression to the most fundamental of individuals' entitlements, and make the weight of this consideration felt in the eventual act of the balancing of different policy options. In other words, it is in the legal nature of human rights law that it simultaneously conditions (and, depending on the situation,

\footnotetext{
${ }^{25}$ For an interesting attempt in the WTO context, see S Cho, 'The WTO's Identity Crisis - Review of Conflict of Norms in Public International Law: How WTO Law Relates to Other Rules of International Law, By Joost Pauwelyn, 2003' (2006) Global Law Books <http://www. globallawbooks.org/reviews/detail.asp?id=53> (10) accessed 3 October 2006: "[C]ross-fertilization or reconciliation [of non-WTO norms and WTO norms] should be the WTO's call ... no other treaties should replace the WTO in that call ... after all, it is all about 'trade and (...) human rights,' not '(...) human rights and trade”. (emphasis in the original).

${ }^{26}$ For example, Krajewski presents his claim that GATS should give priority to the regulatory autonomy of WTO Members as in line both with WTO case law allowing for deference to national regulatory choices and at the same time coinciding with the OHCHR approach which stresses that GATS is to be interpreted as far as possible so as not to constrain governmental action with regard to basic service provision; M Krajewski, 'Public Services and Trade Liberalization: Mapping the Legal Framework' (2003) 6(2) JIEL 341, 346-347. It is argued here that a human rights focus and a non-trade agenda need not always coincide.

27 Jackson (n 6).

${ }^{28}$ M Krajewski, 'Balancing trade and non-trade policy objectives in GATS: Potentials and limits of Article XIV' (2005) BIICL Conference on "the tenth Anniversary of the WTO Dispute Settlement: An Appraisal” 1.
} 
consequently limits or bolsters) traders' and non-traders' functional legal claims. To make this less abstract, in the context of the European liberalisation of education provision it has been correctly observed that there is a "choice [to be made] between societal gains from the provision of higher education as public good and societal gains from increased trade in education services ... [and] that there is a trade-off between the two approaches". ${ }^{29}$ It is suggested here that analysis based on human rights law can help provide a legally relevant formulation of the minimum framework for this type of choice.

Having dealt with some aspects of the meaning a human rights approach to trade and non-trade could have, a few remarks on its function need to be made. An issue that immediately emerges is that liberalisation of education services is not yet very far developed in the EC and WTO context. As a result, it is not easy to say to what extent tensions from the potential inclusion of education provision in the scope of, and their interpretation within, these regimes may lead to practical effects that are better avoided. Therefore, the question can be raised as to the reason for analysing this from the point of view of human rights protection already at this point in time (at the risk of providing a seemingly speculative analysis) rather than exclusively at the stage of the settlement of legal disputes. The answer to this has different aspects.

Firstly, in cases where it is not yet known whether a proposed trade or non-trade policy is likely to promote or undermine human rights, it has been confirmed in the particular context of trade liberalisation by UN treaty monitoring bodies that human rights law requires that a prior assessment be carried out. ${ }^{30}$ In line with this, many human rights advocates have come to see that it may be more effective to think ahead in a constructive way rather than only to engage in ex post criticism of negotiation results. This is not a matter of "if you can't beat them, join them". Rather, it is one of "prevention is better than cure". ${ }^{11}$ To give body to this line of thinking, much work is currently being done to develop a so-called human rights impact assessment. It is an analytical tool, used both ex ante and

${ }^{29} \mathrm{~K}$ Barkholt, 'The Bologna Process and Integration Theory: Convergence and Autonomy' (2005) 30(1) Higher Education in Europe 23, 24.

30 3D Trade - Human Rights - Equitable Economy and Forum-Asia, 'Practical Guide to the WTO For Human Rights Advocates' (2004) <http://www.3dthree.org/en/complement. php?IDcomplement=36\&IDcat $=4 \& I D p a g e=14>(71-72)$ accessed 3 October 2006, referring to the Committee on the Rights of the Child.

${ }^{31}$ Cf. K Tomasevski, 'Globalizing What: Education as a Human Right or as a Traded Service?' (2005) 12 Indiana Journal of Global Legal Studies 78; "Refocusing human rights research from retroactively remedying violations to preventing them is as urgent as it is neglected ... the full mobilization of the existing human rights standards for education can neutralize the negative dimension of globalization at all levels, thus enabling the human rights community to provide a timely contribution to developments, which were, until recently, deemed to lie beyond the reach of human rights safeguards". 
ex post, to evaluate the effects of a policy on specific human rights. ${ }^{32}$ More institutionally, given that trade negotiations are usually the sole competence of trade officials at the domestic level, a final general reason for ex ante analysis is that it may help empower officials of other departments to have their interests heard in the domestic trade departments at a time still relevant to the formulation of positions in trade negotiations. ${ }^{33}$

Secondly, this proactive human rights approach seems to be particularly valid for the GATS context. There is no sector, including education, that is a priori excluded from the current round of negotiations, ${ }^{34} \mathrm{a}$ legal setting known as the "built-in agenda" in trade-speak. This understanding to the effect of liberalising trade in services through successive rounds of negotiations "accentuates the need for ... analysts to be alert to the GATS' possible consequences for national freedoms to plan and operate collective, redistributive, citizen-based [public services]". ${ }^{35}$ Moreover, given the mercantilist nature of international trade negotiations, it is quite likely that requests are made with regard to one sector to compensate for a "sacrifice" in another. Sectors for which the implications of liberalisation have remained under-negotiated and hence under-explored are more vulnerable to be "negotiated away" as a result, ${ }^{36}$ particularly in the proverbial last-minute deals.

\footnotetext{
${ }^{32}$ International Federation for Human Rights, 'Understanding Global Trade \& Human Rights - Report \& Resource Guide for National Human Right NGOs in View of the 2005 WTO Ministerial Conference, Hong Kong' (2005) <http://www.fidh.org/IMG/pdf/wto423a.pdf> (11) accessed 3 October 2006. See also K De Feyter, Human Rights: Social Justice in The Age of the Market (Zed Books, London 2005) 216: "Human rights proponents need proactively to identify the human rights impact of economic globalisation, if human rights are to fulfil their potential as instruments of social protection ... they need to do so at an early stage, when economic norms and mechanisms are being negotiated ... human rights concerns must be part and parcel of the regulation of economic globalisation."

${ }^{33}$ P Rose, R Carr-Hill, K Holmes and T Henderson, Education and the General Agreement On Trade In Services: What does the Future Hold? (The Commonwealth Secretariat, London 2003) 5.

${ }^{34}$ JA Van Duzer, 'Navigating Between the Poles: Unpacking the Debate on the Implications for Development of GATS Obligations Relating to Health and Education Services', in EU Petersmann and J Harrison (eds), Reforming the World Trading System: Legitimacy, Efficiency and Democratic Governance (Oxford University Press, Oxford 2005 (forthcoming)).

${ }^{35}$ N Yeates, 'The General Agreement on Trade in Services: What's in it for Social Security?' (2005) 58(1) International Social Security Review 3, 4.

${ }^{36}$ Cf. S Bjarnason, 'Debate on Education and GATS: Where Do We Stand?' in P. Rose et al. (eds), Education and the General Agreement On Trade In Services: What does the Future Hold? (The Commonwealth Secretariat, London 2003) 16: "The fact that the education sector is one of the least actively negotiated should not give way to a sense of complacency as the negotiators have potentially much larger services on the table from a national perspective. It is possible that if the negotiators (usually departments of trade) are not lobbied persistently by education representatives to enable them to clearly understand the issues from the education sector, then the temptation might well be to make concessions in the education sector in order to gain a stronger position in what might be perceived to be some larger public issue."
} 
A final policy related point necessitating a priori human rights analysis is related to the nature of the likely impact that the GATS regime has on the supply of public services. As Krajewski has convincingly argued, the obligations to grant market access and national treatment are most important for public services, whereas the obligation to grant Most Favoured Nation Treatment is less relevant due to the fact that the public service or the service supplier will usually be a national service (supplier) and not a foreign service (supplier). ${ }^{37}$ As will be shown in the next section, the national treatment and market access obligation only arise once a commitment is made. In other words, the structure of GATS with regard to public services is such that it is important to assess beforehand whether subjection to market access and national treatment can be responsibly done from the perspective of human rights protection.

To sum up the meaning and function of the human rights approach to trade/non-trade, the starting point is that human rights law is, in principle, neutral to both trade and the pursuit of non-trade policies. It can find in each an ally at times and an opponent at others. The fundamental insight therefore is that it is in the intended legal nature of human rights that they condition trade and non-trade alike. As a result, and perhaps confusingly, when trade law collides with non-trade law, human rights law conditions both legal disciplines simultaneously in this clash. This double-edged nature of human rights law in trade/non-trade discussions is precisely the reason why a human rights perspective can be helpful in analysing a legal problem such as service liberalisation vs. education policy. As will be argued below, these negotiations require urgent attention from a human rights perspective for a variety of reasons. It is to such analysis that we will turn in the next two sections of this paper, focusing on the WTO (section 3) and EC contexts (section 4) in turn.

\section{Economic liberalisation of education provision in the WTO context}

The provision of education is one of the public services involving most financial resources. Annual global public spending on education exceeds one trillion dollars. ${ }^{38}$ UNESCO research has shown that within OECD countries as much as $98 \%$ of education spending is public, and that the average is $88 \% .{ }^{39}$ While cross-border education has always been an important aspect of the internationalisation of higher education, it has not been subject to international trade rules and, until recently, has not

\footnotetext{
${ }^{37}$ Krajewski (n 26) 359.

${ }^{38}$ AM Steketee, 'For-Profit Education Service Providers in Primary and Secondary Schooling: The Drive For and Consequences of Global Expansion' (2004) 11 (Summer) Indiana Journal of Global Legal Studies 171, 176.

39 Van Duzer (n 34).
} 
really been described as an activity subject to the discipline of commercial trade. ${ }^{40}$ This section starts with a brief description of the GATS rules. It then goes on to describe the nature and state of the global economic liberalisation/education provision debate. After this, a human rights perspective is introduced in an attempt to start appreciating how claims of free traders and education experts could be critically viewed from the standpoint of the basic entitlements of individuals.

\subsection{The GATS legal framework with particular reference to education provision}

It is important to paint an objective picture of the legal framework governing the global liberalisation of services. GATS is a particularly complex treaty and its working is often mischaracterised. ${ }^{41}$

Article I of GATS defines the scope of the Agreement and the nature of services trade. GATS covers 161 service activities across 12 classified sectors, of which Education is one. The sector of education is subdivided into primary education services, secondary education services, higher education services, adult education, and other education services. GATS contains no definition of education services, nor has a reference paper been drawn up with regard to them (as was done, for example, with telecommunications). ${ }^{42}$ GATS excludes services which are supplied in the "exercise of governmental authority", the latter being defined as services which are supplied neither on a "commercial basis nor in competition with one or more service suppliers" (Article I:3).

GATS defines services trade as occurring through four modes of supply. In the case of education services, these are:

Mode 1: cross-border supply of educational services (on-line learning, distance education, videoconferencing, etc.)

Mode 2: Consumption abroad (international student mobility)

Mode 3: Foreign investment by educational institutions

Mode 4: Movement of natural persons (international teacher mobility) ${ }^{43}$

As far as relevant here, GATS operates a distinction between different obligations. On the one hand, there are general rules and principles governing trade in services, most importantly the disciplines on transpar-

\footnotetext{
${ }^{40} \mathrm{~J}$ Knight, 'GATS, Trade and Higher Education: Perspectives 2003 - Where are We?' (2003) The Observatory on Borderless Higher Education 2.

${ }^{41}$ Cf. R Adlung, 'Public Services and the GATS' (2006) 9(2) JIEL 455, 456; “[M]any statements [about GATS] appear to be influenced by personal prejudice or aversion, rather than by thorough analysis or factual evidence."

42 Van Duzer (n 34).

${ }^{43} \mathrm{~K}$ Larsen and S Vincent-Lancrin, 'International Trade in Educational Services: Good or Bad' (2002) 14(3) Higher Education Management and Policy 9, 11.
} 
ency (Article III) and most favoured nation treatment (Article II). On the other hand, GATS consists of schedules of commitments which outline the liberalisation of each Member. Sectoral schedule commitments concern market access and national treatment within designated sectors. Such commitments identify the services (by mode of supply) for which the Member guarantees market access and national treatment and any limitations that may be attached. Members can also make market access and national treatment commitments across sectors (again for each mode of supply) in what are known as horizontal schedules of commitments. Within the sectoral schedules, an entry of "none" indicates that a Member is bound to not having or introducing any measures which violate market access or national treatment for a specific sector and mode of supply (but any limitations set out in the horizontal schedule may still apply). The term "unbound" indicates that no commitment has been made for a particular mode of supply.

Even if it is not obligatory to respond to demands to open the market of services, WTO Members that wish to continue to protect a certain services sector will de facto have to provide compensating concessions in other sectors in a negotiating round as a result of the WTO's negotiation mantra that no a priori exclusions are allowed..$^{44}$ As has been pointed out by Yeates, this means that GATS potentially covers services of immediate and direct relevance to human welfare - water, energy, health and social care, and education, as well as income support services. ${ }^{45}$ The implication is that the dynamic is one in which it needs to be justified by a state why it does not wish to submit a certain policy area to GATS negotiations, and that protection/exclusion of one area will need to be "paid for" with the inclusion of another.

On the other hand, GATS expressly contemplates that a Member may withdraw trade concessions made in its national schedule in relation to any service sector. However, the Member State wishing to re-negotiate commitments made must wait three years after having listed a commitment before altering it. ${ }^{46}$ Where another Member feels the withdrawal may affect the benefits it receives under GATS, it may request that the withdrawing state enter into negotiations with a view to agreeing on a compensating adjustment typically in the form of other trade concessions. ${ }^{47}$

${ }^{44}$ Guidelines and procedures for the negotiations on trade in services, adopted by the Special Session of the Council for Trade in Services on 28 March 2001, para II.5, S/L/93, (quoted in Krajewski (n 26) fn 348).

45 Yeates (n 35) 7.

46 Ibid 8.

${ }^{47}$ Van Duzer (n 34). See also C Scherrer, 'GATS: long-term strategy for the commodification of education' (2005) 12(3) Review of International Political Economy 484, 487. 


\subsection{Nature and state of the GATS economic liberalisation/education provision discussion}

As was pointed out earlier, up until recently education provision seems not often to have been appreciated in terms of being subject to international trade rules. In fact, before the start of the Doha Development Round in 2001, the value of trade in education services was underestimated. Since then, a more precise picture has emerged of the sector's relative growth in terms of exports and imports, thereby putting education services higher up on the negotiation agenda. ${ }^{48}$

Education services are traded predominantly through student mobility across borders, with students attending public universities in the exporting countries (mode 2: consumption abroad). ${ }^{49}$ This has become big business for some countries. The international market for student mobility amounted to $\$ 30$ billion in exports in 1998, or $3 \%$ of global services export. ${ }^{50}$ In 2004 alone, more than 500.000 foreign students contributed about $\$ 13$ billion to the United States economy. ${ }^{51}$ For Australia, education services represent a value of more than $10 \%$ of its total exports. ${ }^{52}$ Also, commercial presence (mode 3 ) is growing in importance. Here, however, it is to be kept particularly in mind that providers other than traditional universities are emerging, or playing a greater role, including vocational training institutions, private for-profit institutions and distance-learning institutions. ${ }^{53}$

Discussions about the advantages and disadvantages of bringing education within the realm of the WTO have been polarised. Support and opposition towards the economic liberalisation of education provision manifests itself generally across professional boundaries, international organisations, as well as between developed and developing countries. ${ }^{54}$ Very roughly speaking, on the one hand there are those who are antitrade and who believe that education is a public good and should under no circumstance come to be treated as a commodity. On the other hand, there are those who are in favour of trade, who argue that education has

\footnotetext{
${ }^{48} \mathrm{R}$ Saner and S Fasel, 'Negotiating Trade in Educational Services with the WTO/GATS Context' (2003) 59 Aussenwirtschaft 275.

${ }^{49}$ WTO, Education Services - Background Note by the Secretariat' (23 September 1998) S/ $\mathrm{C} / \mathrm{W} / 496$.

50 Larsen and Vincent-Lancrin (n 43) 16

${ }^{51}$ C Lorenz, 'Will the universities survive the European integration? Higher education policies in the EU and in the Netherlands before and after the Bologna Declaration', hand-out, lecture at the University of Michigan, October 2005, fn 12.

52 Saner and Fasel (n 48) 281.

${ }^{53}$ Larsen and Vincent-Lancrin (n 43) 21.

${ }^{54}$ Saner and Fasel (n 48) 299.
} 
been traded for decades, and cannot see the harm in formalising what is happening in any case. ${ }^{55}$

Economic liberalisation proponents maintain that greater liberalisation of the education sector will produce efficiency gains and stimulate innovative practices through market competition. It is argued that GATS will result in increased choice, opportunities for knowledge and technology transfer, and reduced prices. ${ }^{56}$ Moreover, the fact that countries are free to place as many limitations and conditions in their schedules of commitments as they like has led GATS supporters to posit that the agreement allows governments very high levels of flexibility with respect to the obligations they are willing to assume. ${ }^{57}$ Also, the more general expectation that binding multilateral commitments will provide additional benefit for a state in instilling confidence in their policies and signalling stability in their policy intentions has been mentioned in favour of liberalisation. ${ }^{58}$ And even if the application of trade rules leads to problems, these would not necessarily need to be addressed by the WTO itself, as "the WTO is already overloaded; many issues, at least initially, should simply be addressed in other fora". 59

Those advocating against the economic liberalisation of education provision fear that agreeing to the liberalisation of the education sector would open the backdoor to the dismantling of education as a public service via privatisation and deregulation. ${ }^{60}$ Liberalisation commitments are seen as contributing to the development of a two-tier market in education, under which public services will be undermined and those marginalised will see a diminution of badly needed education so that those already better off and better served will benefit. ${ }^{61}$ Critics are also worried about the prospect of national education providers having to compete with transnational providers, which they expect may impact on the integrity and future development of national education. ${ }^{62}$

As has been well observed, it is both surprising and worrisome that very little has been written by educators or trade specialists on the ra-

55 Rose c.s.(n 33) 5.

${ }^{56}$ Ibid 4.

${ }^{57}$ L Mehta and B La Cour Madsen, 'Is the WTO after your Water? The General Agreement on Trade in Services and Poor People's Right to Water' (2005) Natural Resources Forum $154,158$.

58 R Chanda, 'Social Services and the GATS: Key Issues and Concerns' (2003) 31 World Development 1997, 2009.

59 DB Honeck, 'Services 2000: Education and Training' (2000) 25(3) Higher Education in Europe 291, 293.

60 Saner and Fasel (n 48) 293.

${ }^{61}$ Van Duzer (n 34).

${ }^{62}$ Rose c.s. (n 33) 4. 
tionales for and the benefits from the import and export of education services. It appears that rationales are either taken for granted in the overall assumption that liberalised trade will increase a nation's economic prosperity, or are found irrelevant from the preconceived viewpoint that the provision of education should never be traded. ${ }^{63}$ Still for the purpose of engaging in even-handed assessment, it seems valuable to view which different rationales exist.

A whole variety of rationales have been identified for engagement in the liberalisation of education services. Reasons for importing higher education services include increased capacity, access to specialised knowledge and skills, development of human resource capacity, increasing of competition among local higher education institutions, minimising the "brain drain", and improving quality through foreign providers. ${ }^{64} \mathrm{Ex}$ porting education services, on the other hand, is not often a governmental initiative, but more frequently one of particular institutions, such as universities. Rationales for exporting education services include easing excess national capacity, income generation, building up of strategic education alliances, and the internationalisation of domestic institutions. ${ }^{65}$

Whatever one's position, it is clear that from a legal viewpoint the key question about the GATS/public service overlap lies in the extent to which education provision is covered by GATS. For this we need to turn to Article I:3 (b) and (c) GATS, which read as follows:

For the purposes of this agreement

(b) "services" includes any service in any sector except services supplied in the exercise of governmental authority

(c) "a service in the exercise of governmental authority" means any service which is supplied neither on a commercial basis, nor in competition with one or more service suppliers. ${ }^{66}$

\footnotetext{
${ }^{63}$ Knight (n 40) 9.

${ }^{64}$ Bjarnason (n 36) 14.

65 Ibid 15.

${ }^{66}$ The text of the clause in the two other official languages of the WTO (French and Spanish) reads as follows:

(b) les "services" comprennent tous les services de tous les secteurs à l'exception des services fournis dans l'exercice du pouvoir gouvernemental;

(c) un "service fourni dans l'exercice du pouvoir gouvernemental" s'entend de tout service qui n'est fourni ni sur une base commerciale, ni en concurrence avec un ou plusieurs fournisseurs de services.

(b) el término "servicios" comprende todo servicio de cualquier sector, excepto los servicios suministrados en ejercicio de facultades gubernamentales;

(c) un "servicio suministrado en ejercicio de facultades gubernamentalesČ significa todo servicio que no se suministre en condiciones comerciales ni en competencia con uno o varios proveedores de servicios.
} 
In 1998 the WTO Secretariat itself stated that "basic education [i.e. primary and secondary education] provided by the government may be considered to fall within the domain of ... services supplied in the exercise of governmental authority (supplied neither on a commercial basis nor in competition)". ${ }^{67}$ In June 2002 this was reiterated by the WTO DirectorGeneral and the Chairman of the WTO Council for Trade in Services, who stated that education services were included under the heading of public services according to the tacit understanding of the definition used by negotiators. ${ }^{68}$ However, as it was put by Larsen en Vincent-Lancrin, even if "this was a strong signal ...it did not rule out a change of interpretation in the future", ${ }^{69}$ particularly as the phrasing represents a compromise that has been described in terms of being an example of "constructive ambiguity ${ }^{-70}$

Some WTO case law may suggest what the Article I:3(b)/(c) GATS wording of "exercise of governmental authority" could be taken to mean. Leroux has found that the Appellate Body could be understood as linking this wording to "the exercise of a power to regulate, control or supervise individuals or entities, or otherwise restrain their conduct, through the exercise of lawful authority". ${ }^{71}$ It is then inferred that on these terms the exercise of governmental authority "has little to do with commerce, trade, and 'mere matters of business' ... that is, the pursuit of activities mainly, if not exclusively, for financial gain." 72

By way of supplementary means of interpretation of Article I:3(b) GATS, it is worthwhile pointing out in the context of this paper that the EC has repeatedly stated that in its opinion the meaning of this phrase is similar to that of Article $45 \mathrm{EC}$ (applicable to freedom to provide services through Article 55 EC).$^{73}$ This relevant phrase reads: the provisions of this chapter shall not apply, so far as any given Member State is concerned, to activities which in that State are connected, even occasionally, with the

${ }^{67}$ WTO, Education Services - Background Note by the Secretariat (23 September 1998) S/C/ $\mathrm{W} / 49$ 3-4. This implies that that it sees higher education as different, and fully subject to the discipline of GATS. It will be explained in the following subsection how this is relevant.

${ }^{68}$ See also Tomasevski (n 31) 14; "GATS allows exempting services provided 'in the exercise of public authority', which comprises public compulsory education in the domestic legislation of most countries" (footnotes omitted).

${ }^{69}$ Larsen and Vincent-Lancrin (n 43) 27.

${ }^{70}$ EH Leroux, "What is a "Service Supplied in the Exercise of Governmental Authority" under Article I:3(b) and (c) of the General Agreement on Trade in Services?' (2006) 40(3) Journal of World Trade 345, 345.

${ }^{71}$ Ibid 352 (referring to Canada-Dairy (13 October 1999) WT/DS103/AB/R).

72 Ibid.

${ }^{73}$ Leroux (n 71) 359. 
exercise of official authority. ${ }^{74}$ On the basis of the fact that the English GATS text speaks of "governmental" and the EC text of "official" authority, it has been argued that the texts are legally different, and therefore that Article 45 EC "is unlikely to have any significant impact on the interpretation of Article I:3(b) and (c)" ${ }^{75}$ This point is not, however, convincing as it hinges on but one of the relevant language versions. Parallel consideration of other official languages of Article I:3 GATS in comparison with the versions of Article $45 \mathrm{EC}$ shows that various different, but very similar, wordings are used. ${ }^{76}$ Therefore, Article 45 EC, and EC services case law, should be seen as making for relevant supplementary means of interpretation of what constitutes "exercise of governmental authority" as a matter of WTO law. ${ }^{77}$

Be that as it may, the interpretational problem remains that Article I:3(c) GATS defines governmental authority in connection with the economic context of the supply and not on the basis of the public interest nature of an activity. As a result, it is not possible to claim that certain services are a priori and permanently excluded from the scope of GATS because of their nature as public or governmental services. After all, economic circumstances change over time, ${ }^{78}$ and the state invoking the exemption is likely to have to bear the burden of providing evidence, which may be hard. In the face of these linguistic ambiguities in Articles I:3(b)/ (c) GATS, it cannot be a priori excluded that the provision of education

${ }^{74}$ The text of the clause in French and Spanish reads as follows:

Sont exceptées de l'application des dispositions du présent chapitre, en ce qui concerne l'État membre intéressé, les activités participant dans cet État, même à titre occasionnel, à l'exercice de l'autorité publique.

Las disposiciones del presente capítulo no se aplicarán, en lo que respecta al Estado miembro interesado, a las actividades que, en dicho Estado, estén relacionadas, aunque sólo sea de manera ocasional, con el ejercicio del poder público.

${ }^{75}$ Leroux (n 71) 359.

${ }^{76}$ See nn 66 and 74 (pouvoir gouvernemental v. autorité publique and facultades gubernementales v. poder público).

${ }^{77}$ It should be added here that there is an aspect to the comparison of WTO and EC legal texts regulating services that may in fact lead to diverging meanings relevant for the purpose of assessing the definition of public services. It is the wording of "provision for remuneration" in article $49 \mathrm{EC}$ on the one hand and that of "on a commercial basis" in article I:3(c) GATS. The ECJ's interpretation of the notion of "for remuneration" has been that it does not require the supply of a service with the intention of making a profit. See, for example, G Davies, 'Welfare as a Service' (2002) 29(1) Legal Issues of Economic Integration 27, 30: "Profit as a marker of economic services ... is dead ... At most it may serve a very general indicator of an economic outlook, which may be useful where it is not clear if money changing hands is in fact consideration or not". On the contrary, the GATS wording of "on a commercial basis" would seem clearly to point to a profit-making intention. The relevance of this issue for the interpretational value to GATS law of EC services case law (some other aspects of which are discussed in section 4.1 below) would seem worthy of further analysis, for which there is no space here.

${ }^{78}$ Krajewski (n 26) 353. 
may well come to be seen as not exempt from the sectoral scope of GATS, and interpreted as not "supplied in exercise of governmental authority". In that light, there is a real possibility that under GATS the provision of (parts of) education will be characterised, and treated, as a service. ${ }^{79}$

\subsection{An initial human rights perspective of the economic liberalisation of education provision}

A good starting point for a human rights analysis of the liberalisation of trade in services is the observation that very little is known about the interplay of GATS and human rights in general terms. After all, GATS is a relatively recent treaty that came into force only in the middle of the 1990s. A fascinating attempt for human rights lawyers and development economics to find common ground concluded that a review of GATS should be conducted to identify intersections between GATS and the implementation of economic and social rights. ${ }^{80}$ This section will take up that challenge by attempting to provide some initial lines of thought on the interface of economic liberalisation and education provision.

Interestingly, the WTO Secretariat itself has acknowledged that "given its importance for human and social development, countries throughout the world tend to consider instruction up to a certain level - commonly primary and secondary education - as basic entitlement". ${ }^{81}$ The question then is, of course, what states should be doing in the context of trade negotiations and adjudication to act upon the legal obligation corresponding to the individual entitlements, and how to go about finding this out. In the remainder of this section, it is proposed to look mainly at the human right to education, fully aware that this is a somewhat simplified picture, as many other human rights norms could also play a role. ${ }^{82}$

Even if there already are "quite a few countries where education is both a right and a traded service", ${ }^{83}$ a pragmatic way of beginning a human rights law analysis would be to study what the most important reasons are for avoiding commitment in education services at this stage. These have been identified as relating, firstly, to uncertainty about the scope and nature of GATS obligations, and, secondly, the likelihood of,

\footnotetext{
79 Ibid 358.

${ }^{80}$ R Balakrishnan, 'Why MES with Human Rights? Integrating Macro Economic Strategies with Human Rights' <http://www.policyinnovations.org/media/1189_Why_MES_with_Human_Rights.pdf> (38) accessed 17 October 2005.

${ }^{81}$ WTO, Education Services - Background Note by the Secretariat'(23 September 1998) S/ $\mathrm{C} / \mathrm{W} / 493$.

${ }^{82}$ For example, those relating to participation in cultural life and non-discrimination. For a recent analysis of the latter issue in the context of education, see LS Bibbings, 'Widening Participation and Higher Education' (2006) 33(1) Journal of Law and Society 74.

83 Tomasevski (n 31) 5.
} 
and conditions for, governments wanting to adopt future policies in education that may be inconsistent with specific commitments in GATS. ${ }^{84}$

A first general point about GATS' potential bite regarding public services is that its focus seems to be on the particular activities, and not on the institution providing them. In other words, GATS mainly has a functional concern, not an institutional one. ${ }^{85}$ Therefore, it was rightly observed that it is misplaced to think that once, say, a university develops one commercial service, all its other activities provided non-commercially and non-competitively will be affected and equally considered a service (and therefore impossible to "protect" by exclusion from GATS's scope). As Adlung has written, "Article I:3 refers explicitly to the conditions governing the supply of a particular service and not to its overall role within a supplier's accounting system or to the existence of remunerative activities that might be conducted in parallel". ${ }^{86}$

Another particularly relevant issue from the point of view of human rights with regard to scope concerns the status of privatised education provision. Privatisation challenges the traditionally state-centred premises of both international trade law and human rights law. It has been correctly written that "... the liberalisation of trade in education services does not per se bring privatisation of education...". ${ }^{87}$ However, this does not diminish the issue of the applicability of the public services exemption of Article I:3 GATS as one that is especially hard to assess now that more and more states chose to privatise some of these services. ${ }^{88}$ On the other hand, it has been argued that the "constructive ambiguity" of Article I:3(b)/(c) GATS still effectively hides a state-centred anchoring of the exemption, namely as a result of the combination of the functional wording ("on a commercial basis/in competition") with the implicit institutional wording ("governmental"): "This could prompt speculation about a third [and hidden] criterion [in Article I:3 GATS], the direct participation of a governmental agency". ${ }^{89}$

This requires us to address the difficult issue of privatisation in human rights law, and in particular with regard to the right to education. As has been well written about this issue generally,

\footnotetext{
${ }^{84}$ Van Duzer (n 34).

85 Adlung (n 41) 455.

86 Ibid 463.

87 F Coomans and AHallo De Wolf, 'Privatisation of Education and the Right to Education' in K De Feyter and F Gomez Isa (eds), Privatisation and Human Rights in the Age of Globalisation (Intersentia, Antwerp 2005) 252.

88 Leroux (n 70) 385.

89 Adlung (n 41) 466 (emphasis added).
} 
privatisation ... makes the connection between payment and ... provision more visible, but it need not make access to basic ... services dependent on people's ability to pay ... what matters, from a human rights perspective, is the sufficiency of ... basic services ... private and state-run systems of [basic service] delivery are at similar risk of failure [or success] in this regard. ${ }^{90}$

As with all human rights, the right to receive education is primarily directed at the state, and therefore only obliges governments to provide, or to allow for adequate educational facilities. However, in line with the above quotation, this does not mean - perhaps contrary to widespread belief in human rights circles - that all schools, vocational training institutions, and universities must be established and maintained by the government exclusively. ${ }^{91}$ If there are sufficient private facilities, a state may fulfil its human rights protection obligations by ensuring that all conditions laid down in international law, such as those relating to education provision or general and equal access to secondary and higher education, are guaranteed by means of, for example, legislative measures, state supervision, and subsidies. ${ }^{92}$

On the other hand, this implies - perhaps contrary to widespread belief in trade economics circles - that human rights law does require states to take appropriate steps to prepare for a changed role, from supplier/ provider to supervisor/regulator ${ }^{93}$ of the provision of education if this has happened or is planned. ${ }^{94}$ This is also to be checked by courts. The European Court of Human Rights, for example, has ruled that a state cannot absolve itself from responsibility by delegating its obligations to private school bodies, ${ }^{95}$ in particular since it has been correctly pointed out that

${ }^{90}$ MG Bloche, 'Is Privatisation of Health Care a Human Rights Problem?' in K De Feyter and F Gomez Isa (eds), Privatisation and Human Rights in the Age of Globalisation (Intersentia, Antwerp 2005) 219. See also G Davies, 'The Process and Side-Effects of Harmonisation of European Welfare States' (2006) Jean Monnet Working Paper 02/06 <http://www.jeanmonnetprogram.org/papers/06/060201.pdf> (7) accessed 3 October 2006: "[I]t is possible for private providers within a well-enough regulated market to provide good quality services, even in a sensitive area such as welfare... [The narrow functional point is that] good ... education ... can be provided to a population by institutions not owned by the state, but subject to regulation imposing certain obligations of equality and universality."

${ }^{91}$ M Nowak, 'The Right to Education' in A Eide et al. (eds), Economic, Social and Cultural Rights - a Textbook (Martinus Nijhoff Publishers, Dordrecht 1995) 200-201.

92 Ibid.

${ }^{93}$ For this terminology, see C Graham, 'Human Rights and the Privatisation of Public Utilities and Essential Services' in K De Feyter and F Gomez Isa (eds), Privatisation and Human Rights in the Age of Globalisation (Intersentia, Antwerp 2005).

94 Steketee (n 38) 203: "Countries that open trade in ... services must also consider an altered role for the state in overseeing the delivery of these services ... the state is likely to take a more regulatory role to ensure the service is delivered as needed...."

95 Coomans and Hallo De Wolf (n 87) 235. 
a freer market may in some ways require closer supervision. ${ }^{96}$ There is no reason not to seek global application of this reasoning.

Importantly then, by way of an interim observation, the GATS wording of "governmental authority" ("pouvoir gouvernemental"/"facultades gubernamentales") seems able to accommodate the requirement of human rights law that a state needs to maintain a measure of control without necessarily institutionally supplying a service itself. The terminology of "authority" would seem sufficiently wide to facilitate the more supervisory obligations of the state if privatisation is opted for. As a matter of human rights law, the possible implicit "direct participation" element of Article I:3(b)/(c) GATS as identified by Adlung is functional, not institutional.

Second, there is also an important human rights law aspect in the assessment of the likelihood of, and conditions for, governments wanting to adopt future policies in education that may be inconsistent with specific commitments in GATS. It has been written by OECD officials that "each country is free to decide nationally to what extent it will publicly finance higher education for its own citizens ... this prerogative cannot be called into question by the development of trade in education services, nor by GATS negotiations on liberalisation". ${ }^{97}$ The point about this observation is that, from a human rights perspective, it misses the point. Here we need to refer back to the remark made in section 2 to the effect that, from an international human rights perspective, reference to national autonomy may ring hollow. This is particularly so since, in the context of public services, what is at stake is the right of access to the service, which requires an active stance of a state ${ }^{98}$ In this case, a state is not "free" to do what it pleases, but is bound by a positive obligation to offer what is required by norms relating to education provision, including the provision of "free" education.

At this point it then becomes necessary to look in more detail at the human right to education, and the way in which it has been interpreted. The core of the right to education under international law is constituted by the right of every human being, and of children in particular, to receive education..$^{99}$ Education rights are dependent on various factors, as has been clarified by the Committee monitoring compliance with the International Covenant on Economic, Social and Cultural Rights (CESCR). For education rights to be sufficiently guaranteed, they must be available,

\footnotetext{
${ }^{96}$ Davies (n 90) 53.

97 Larsen and Vincent-Lancrin (n 43) 27 (see also Chanda (n 58) 2005: "governments are free to define and treat government services as they decide... they do not need to notify or explain their definition").

98 Graham (n 93).

99 Nowak (n 91) 198-199.
} 
accessible to all (physically, economically, and in a non-discriminatory way), acceptable (relevant, culturally appropriate, and of good quality) and adaptable to diverse social and cultural settings. ${ }^{100}$ In other words, while education can be instrumental in making declared rights effective within societies, education rights for all can only be fully operational in the context of wider rights of non-discrimination and of the recognition of cultural and social diversity. ${ }^{101}$

It is instructive to study the wording of the human right to education as present in the UDHR, ${ }^{102}$ the ICESCR, ${ }^{103}$ and the CRC. ${ }^{104}$ A first common feature is the break-up in levels of education which conveniently coincides with the GATS classification. Moreover, it seems clear that the main requirement of the right to education relates to its provision free of

${ }^{100}$ Committee on Economic, Social and Cultural Rights, General Comment 13, The Right to Education (December 1999) E/C.12/1999/10 para 6.

${ }^{101} \mathrm{C}$ Wallace and J Shaw, 'Education, Multiculturalism and the Charter of Fundamental Rights of the European Union' in TK Hervey and J Kenner (eds), Economic and Social Rights under the Eu Charter of Fundamental Rights - A Legal Perspective (Hart Publishing, Oxford 2003) 238.

102 Article 26 Universal Declaration of Human Rights

1. Everyone has the right to education. Education shall be free, at least in the elementary and fundamental stages. Elementary education shall be compulsory. Technical and professional education shall be made generally available and higher education shall be equally accessible to all on the basis of merit....

103 Article 13 International Covenant on Economic, Social and Cultural Rights

1. The States Parties to the present Covenant recognise the right of everyone to education. .....

2. The States Parties to the present Covenant recognise that, with a view to achieving the full realization of this right:

(a) Primary education shall be compulsory and available free to all;

(b) Secondary education in its different forms, including technical and vocational secondary education, shall be made generally available and accessible to all by every appropriate means, and in particular by the progressive introduction of free education;

(c) Higher education shall be made equally accessible to all, on the basis of capacity, by every appropriate means, and in particular by the progressive introduction of free education;

(d) Fundamental education shall be encouraged or intensified as far as possible for those persons who have not received or completed the whole period of their primary education;

....

\section{${ }^{104}$ Article 28 Convention on the Rights of the Child}

1. States Parties recognise the right of the child to education, and with a view to achieving this right progressively and on the basis of equal opportunity, they shall, in particular:

(a) Make primary education compulsory and available free to all;

(b) Encourage the development of different forms of secondary education, including general and vocational education, make them available and accessible to every child, and take appropriate measures such as the introduction of free education and offering financial assistance in case of need;

(c) Make higher education accessible to all on the basis of capacity by every appropriate means; .... 
charge. This term comprises direct, indirect, and opportunity costs, and points to the governmental obligation to eliminate all those costs that preclude the completion of schooling. ${ }^{105}$

Problematically, however, the mentioned human rights treaties have strikingly different requirement in this regard. The UDHR requires free provision of primary and adult education. The ICESCR requires immediate free provision of primary education (Article 13(2)(a) and the progressive introduction of free secondary education, vocational training (Article 13(2)(b)) and higher education (Article 13(2)(c)). The CRC is similar to the ICESCR, with the exception that it does not mention the introduction of the free provision of higher education (although this may be explained by the fact that people usually embark upon higher education once they are no longer a child, and hence stop being covered by the CRC). It should be stressed that this is a legal problem, in light of the wide ratification amongst WTO Members of the ICESCR and CRC. On the other hand, the requirement of "free provision" is also of a surprisingly economic nature, which could be interpreted that the financing cannot under any circumstances be based in any significant part on contributions of those receiving primary and secondary education.

The most relevant aspect of this legal dilemma, to which the discussion will be limited here, is the status of the progressive introduction of free higher education. With regard to the requirement of provision free of charge, the CESCR has stated, initially with regard to primary education, that fees imposed by the Government, the local authorities or the school, and other direct costs, constitute disincentives to the enjoyment of the right, and may jeopardise its realisation, and that they are often highly regressive in effect. ${ }^{106}$ It has later characterised this as its general understanding of what the obligation of "free" envisages, ${ }^{107}$ i.e. it also applies to other levels of education. Of particular relevance here is that it has not qualified its view of this meaning with regard to higher education. ${ }^{108}$ As a logical flip-side to this line of reasoning, the CESCR has pointed out that the principle of progressive realisation means that, at the very least, current levels of free provision cannot be rolled back. ${ }^{109}$

\footnotetext{
105 Tomasevski (n 31) 16.

106 Committee on Economic, Social and Cultural Rights, General Comment 11, Plans of Action for Primary Education (May 1999) E/C.12/1999/4 para 7.

107 Committee on Economic, Social and Cultural Rights, General Comment 13, The Right to Education (December 1999) E/C.12/1999/10 para 14.

108 Ibid para 20. See, however, S Grover, 'Secondary Education as a Universal Human Right' (2004) 16(1) Education and the Law 21, 21, who claims that "there is ... no legal obligation stipulated in international human rights law for the States Parties to the UN Conventions to provide free, compulsory education to the end of secondary school". The author does not, however, refer to the ICESCR (only to the UDHR and the CRC), nor does she explain or justify this omission.

$1093 \mathrm{D}$ (n 30) 53-54.
} 
In that light, there seems to be genuine scope for tension between progressive economic liberalisation and the progressive realisation of social human rights, particularly given that patterns of (re-)introduction of charges show that they generally result from poverty. ${ }^{110}$ This argues in favour of clearly circumscribing the way in which higher education provision should be subject to GATS, and particularly in the situation of a developed country seeking access to the education provision "markets" of developing countries.

On the other hand, there may also be scope to give a less rigid (and perhaps more pragmatic) meaning to "free" provision that would focus less on the level of subsidy, but instead give parallel weight to the societal context of this individual entitlement (e.g. the economic situation of the family, social and ethnic origin, etc.). ${ }^{11}$ This more contextual understanding of "free provision" may facilitate an escape from the paradoxical terminological straightjacket of an overly economic nature, in that it can help argue the case more from the basis of the rationale of access to the education system. Rigid insistence on the requirement of education "for free" may lead to losing sight of the fact that, for both the individual and society, financing education is the (necessary) means to an end, not the end in itself.

Even if the above may suggest that human rights functionally condition the way in which education can be (allowed to be) provided in market conditions, it is worth stressing that this need not lead to a priori exemption from economic liberalisation. For one thing, there may be plenty of room for gaining flexibility and efficiency ${ }^{112}$ within the enormous budgets already available for education. Human rights protection as such does not stand in the way of states' political choices to privatise education, to free its hands for other tasks, nor to allow in foreign providers. A correct understanding of the requirement of movement toward progressive "free" provision would, however, force a state to insist, as general regulator, that the financial contribution required of students would not be raised in a way that would be at odds with the rationale of access to education for all.

On the basis of this type of consideration, some commentators have proposed elements for what could be seen as a human rights precaution-

\footnotetext{
${ }_{110}$ As the former special rapporteur on the right to education has argued: "Supplanting previously free by for-fee education is ... the biggest challenge to education as a human right ... progressive liberalisation of trade in education ... is replacing progressive liberalisation of economic, social, and cultural rights ... unless this is effectively countered, we may continue talking about economic, social, and cultural rights but purchasing power will have replaced entitlements"; Tomaševski (n 24) 710. See also Tomasevski (n 31) 24.

111 Cf. Bibbings (n 82).

112 Coomans and Hallo De Wolf (n 87) 242.
} 
ary principle in the context of trade liberalisation. As Koen de Feyter has written:

"From a human rights perspective, it is essential that GATS negotiators: (i) delay opening markets in human-rights-sensitive services to private foreign operators until they have ensured that the domestic legal system provides the specific human rights protection necessary to prevent and redress the potential adverse human rights impacts of the liberalisation/privatisation process; and (ii) ensure that GATS commitments are drafted in such a way that the state preserves the necessary regulatory capability to comply with its human rights duties after the relevant service has been brought under the GATS scheme". ${ }^{113}$

Finally, then, in this section of the paper, it has been argued that a human rights perspective of trade and non-trade does not have a preset opinion of the virtue of trade liberalisation, but pragmatically considers case by case. Yeates has pointed to an interesting situation where trade law non-discrimination may coincide with human rights non-discrimination, because whereas "temporary migrant workers are often required to pay taxes for a public service without a corresponding entitlement to receiving benefits... one of the possible effects of the GATS ... is its potential to improve entitlement to social public services of temporary migrant workers". ${ }^{114}$

\section{Economic liberalisation of education provision in the EC context}

Looking at the same type of issues in the EC setting may for a moment leave an observer entirely alienated. For all its obvious legal and systematic similarities, the EC discussion progresses in a parallel universe. Nonetheless, it will be attempted next to appreciate EC developments in terms of the impact of economic liberalisation on education provision. Although many more different aspects of EU law may be relevant to the human rights analysis of the liberalisation of education services in the EC context - such as free movement of workers, and the EC's competences in the field of education - this paper will give a flavour of the nature and state of the EC debate through a very simplified juxtaposition of ECJ services case law with the provisions on common commercial policy.

\subsection{The nature and state of the discussion of EC economic liberalisation vs. education provision through a discussion of ECJ case law and common commercial policy provisions}

Rapid development is taking place in case law concerning the way the provision of public services is subject to Article $49 \mathrm{EC}$. As was pointed

\footnotetext{
113 De Feyter (n 32) 202.

114 Yeates (n 35) 18.
} 
out earlier, the ECJ has ruled that the provision of national education, as long as it is largely financed from the public purse, is not a service and therefore not subject to the EC legal discipline of free movement of services. ${ }^{115}$ A regime not seeking gainful activity but fulfilling a duty towards the population in social, cultural and educational fields does not constitute a service. ${ }^{116}$ With regard to the terminology of "largely", it has been suggested that education retains its non-economic nature as long as a majority of funds are of public origin. ${ }^{117}$ Therefore, this also implies that states need to continue to pay for most of education provision if they intend to keep this public service excluded from the EC services discipline. ${ }^{118}$ A second element of the formula is the suggestion that it is somehow of significance that a state fulfils its duty to its population. ${ }^{119}$

A first qualification of this Humbel/Wirth position on education provision is that the exclusion from the application of the economic law governing services is likely still only to hold water for public education. In the recent Neri, the organisation for remuneration of university courses by a private educational institution was characterised as an economic activity by the ECJ, and thus interpreted as subject to the discipline covered by the freedom of establishment. ${ }^{120}$ This presumably means, although the ECJ did not itself explicitly state this, that organisation for remuneration of university courses by a private educational institution will also be characterised as service provision. ${ }^{121}$ This would be an important finding, as it would make such private education provision subject to the full force and logic of economic law, and therefore condition how states can regulate this policy-area. ${ }^{122}$ C-153/02 Valentina Neri para 46. Another argument that the holding in Neri would likely lead to a characterisation as service of private higher education is that it could trigger the Court's argumentation in Wirth (n 1) para 17, to the effect that where a higher education establishment was financed essentially out of private funds, such as students' fees or parents' contributions, and sought to make a profit, it could then be a service provider; Cf. Davies (n 77) 29 (describing this part of the Wirth-reasoning as obiter dictum).

${ }^{122}$ It should be added here that there are of course many rules of EC primary law other than the four freedoms that influence how states can regulate their education system. For a recent case in which the Court overturned a national system's education regulations amounting to discrimination on the grounds of nationality, see Case C-147/03 Commission of the European Communities $v$ Republic of Austria [2005] ECR I-5969. For a case in which
} 
This leads us to a second observation. Of great relevance for our discussion is that the ECJ has held that public services other than, but in some respects very similar to, public education provision fall within the scope of the EC Treaty provisions on the freedom to provide services. In particular, even if the ECJ was invited to exclude it in line with the abovementioned Humbel reasoning, ${ }^{123}$ the Court has in fact recently legally qualified the provision of public health care as a service in a series of cases. ${ }^{124}$ It now considers the sector as a whole to consist of activity of an economic nature, whether involving public or private institutions. ${ }^{125}$ This means that concerns such as those relating to the viability of the public service provision, or the increased costs resulting from opening the national system, can only be considered at the stage of exception and justification for restrictions to the freedom of provision of services. ${ }^{126}$ This could have a number of important strategic and substantive disadvantages for those in charge of safeguarding the public service, as they find themselves placed in a defensive position ${ }^{127}$ and forced to phrase their concerns in terms of legal arguments not essentially based in welfare law or policy. ${ }^{128}$

The exclusion of public education provision from the legal discipline of free movement of services has therefore become increasingly odd in

the Court overturned a national system's education regulations on the ground of the citizenship provision of article 18 EC, see Case C-209/03 The Queen (on the application of Dany Bidar) $v$ London Borough of Ealing and Secretary of State for Education and Skills [2005] ECR I-2119. For a good analysis of this type of case, see G Davies, 'Higher Education, Equal Access, And Residence Conditions: Does EU Law Allow Member States to Charge Higher Fees To Students Not Previously Resident?' (2005) 12(3) Maastricht Journal of European and Comparative Law 227. The point addressed in this section is solely that of the EC law status of education provision under the EC freedom to provide services. This narrow focus is chosen both for the purpose of comparative legal assessment of the EC and WTO legal situation with regard to public services as well as for the purpose of appreciating the consistency of EC Member States' behaviour with regard to this issue in the context of the WTO.

123 Opinion of AG Ruiz-Jarabo Colomer, case C-157/99 B.S.M. Geraets-Smits $v$ Stichting Ziekenfonds VGZ and H.T.M. Peerbooms $v$ Stichting CZ Groep Zorgverzekeringen [2001] ECR I-5473.

${ }^{124}$ See, for example, case C-158/96 Raymond Kohll $v$ Union des caisses de maladie [1998] ECR I-1931, case C-368/98 Abdon Vanbraekel and Others $v$ Alliance nationale des mutualités chrétiennes (ANMC) [2001] ECR I-5363, case C-157/99 B.S.M. Geraets-Smits v Stichting Ziekenfonds VGZ and H.T.M. Peerbooms $v$ Stichting CZ Groep Zorgverzekeringen [2001] ECR I-5473, case C-385/99 V.G. Müller-Fauré v Onderlinge Waarborgmaatschappij OZ Zorgverzekeringen UA and E.E.M. van Riet $v$ Onderlinge Waarborgmaatschappij ZAO Zorgverzekeringen [2003] ECR I-4509, and case C-372/04 The Queen, on the application of Yvonne Watts $v$ Bedford Primary Care Trust and Secretary of State for Health, ECJ judgment of 16 May 2006.

125 Davies (n 90) 20.

${ }^{126}$ Davies (n 77) 37.

127 Davies (n 90) 29.

${ }^{128}$ Ibid 5. 
the light of the far-reaching subjection of the provision of health care. In fact, the developments in the judicial appreciation of the public service of health care provision raise the issue of the very remaining value of Humbel as a precedent with regard to the activity in the context of which it was decided: public education provision. ${ }^{129}$ It has been argued that since the Humbel ruling, the contribution of fees to funding has become more important and the behaviour of universities more competitive and market-like. ${ }^{130}$ For example, most postgraduate courses are now of an economic nature. ${ }^{131}$ More generally, it has been suggested that the process of harmonisation of national education systems is at an earlier stage than that of health care provision, without there being important conceptual differences. ${ }^{132}$ This would suggest that it is only a matter of time for public education to be characterised as an economic activity, and therefore as a service.

The core question at this stage therefore is this: are there elements that inherently distinguish education provision from health care provision, and the concomitant role of the state in such provision? It will be suggested here that education is indeed importantly different, and should be treated as such. In the next subsection, an attempt will be made to further strengthen this viewpoint with reference to human rights.

A first difference between health and education provision is that in the context of higher education remuneration may be harder to locate as a result of cross-subsidy between faculties and between different functions and sources of funds within faculties. ${ }^{133}$ In a recent Opinion, AG Jacobs pointed at two further differences between public health provision and public education provision when he argued that "patients move across borders more as a matter of necessity, whereas students do so more as a matter of choice ... also ... patients move to receive specific medical treatment after which they return to their home state ... students on the other hand stay for the whole period of their studies, participate in the local social and cultural life and ... will tend to integrate in the host Member State". ${ }^{134}$ While the general validity of his first observation of a structural nature may actually be directly questioned, ${ }^{135}$ the second more

129 Opinion of AG Geelhoed, case C-372/04 Watts, delivered on 15 December 2005, para 60: “...disregarding whether Humbel may still be regarded as good law...”.

130 Davies (n 90) 21.

131 Davies (n 77) 32.

132 Davies (n 90) 24.

133 Ibid 21.

${ }^{134}$ Opinion of AG Jacobs, case C-147/03 Commission v. Austria [2005] ECR I-5969 para 35.

${ }^{135}$ For example, many German students come to the Netherlands as they cannot study the subject of their choice in their home country for reason of a numerus fixus. 
principled issue may lead to the core of the difference between health care and education.

Of all public services, education may have the greatest cultural and social cohesive force. To paraphrase Davies here, "state provision of education could be seen as a part of the essential structure of the state" and "an element of national composition". ${ }^{136}$ As he explains well, ${ }^{137}$ the collective bonding coming from a shared educational experience resulting from enjoying one's student life within state schools and universities is lost when education provision becomes too fragmented and diversified. It is indeed the case that "the effect of this, and of losing it, should not be underestimated" 138 even if the quality of the education nation-wide is sustained - or perhaps even when raised by a certain degree, in a scenario that it would benefit individuals but at a greater cost to society at large.

In other words, due to education's specific nature in forming individuals and shaping societies, it is argued that there are important reasons to maintain the exclusion of public education provision from the EC services law discipline.

An interesting recent addition to this internal debate is the negotiation on the Bolkestein Directive about further liberalisation of the EC services markets. The European Parliament's Legislative Resolution ${ }^{139}$ clearly aimed at excluding education provision from the scope of the proposed directive. Its recital 16 sums up the Parliament's view:

The concept of service covers any economic activity normally provided for remuneration. The characteristic of remuneration is absent in the case of activities performed, for no consideration, by the State ... in the context of their duties in the ... educational field..., whether at public or private educational establishments... These activities are not covered by the definition of "service" and do not therefore fall within the scope of this Directive. ${ }^{140}$

\footnotetext{
${ }^{136}$ Davies (n 90) pp 36 and 61.

137 Ibid 50.

138 Ibid.

139 European Parliament Legislative resolution on the proposal for a directive of the Parliament and the Council on services in the internal market (16 February 2006).

140 See also, for example:

- new recital 7c): “... educational ... services typically pursuing social welfare objectives should not be affected by the provisions of this directive"

- new recital 8a): “... as regards services of general interest, this Directive covers only services that correspond to an economic activity and are open to competition"

- adapted recital 15: "The payment of a fee by recipients in order to make a certain contribution to the operating expenses of a system does not in itself imply remuneration because the service is still essentially financed by public funds."
} 
Much of the legal strength of this claim seems lost, however, when recital 24 attempts to add education to the list of mandatory requirements, which implies, of course, that education provision is believed to be covered by the scope of the services directive, for otherwise there would be no need for exclusion through an exceptions clause. ${ }^{141}$ It should be noted, however, that this seeming contradiction of mentioning education both in the context of exclusion from the scope of the EC services law discipline and as a mandatory requirement is sustained in the more recent Common Position adopted by the Council. ${ }^{142}$

In striking contrast to (public) education provision's apparent exclusion from the EC services law discipline, the common commercial policy provisions of the current EC Treaty lay down the possibility of committing to liberalising education services, although according to a particularly burdensome procedure. Article 133(6), para. 2 EC reads: "Agreements relating to ... educational services ... shall fall within the shared competence of the Community and its Member States. [I]n addition to a Community decision taken in accordance with ... Article $300 \mathrm{EC}$, the negotiation of such agreement shall require the common accord of the Member States".

EU countries have made commitments for privately funded education institutions in all subsectors except "other". ${ }^{143}$ The EC has not (yet) offered commitments with regard to publicly financed education services. ${ }^{144}$ The proposed EC revised offer in the Doha negotiations took pride in not containing commitments in "sensitive areas" such as education. ${ }^{145}$ Equally, the EC request in the current global trade negotiations stated that it "does not seek commitments that would dismantle public services". ${ }^{146}$ Realistically, however, in the current political setting it is far

${ }^{141}$ It is possible that recital 24 is a slip of the pen, as the addition to mandatory requirements is inconsistently done throughout the text of the Legislative Resolution, e.g. education is not added in new recital 27, and in particular it is not added in amended recital 29 which has a very long list of overriding reasons relating to public interest.

${ }_{142}$ Common Position adopted by the Council with a view to the adoption of a Directive of the European Parliament and of the Council on services in the internal market [2006] Doc 10003/06, in recitals 34 and 40 respectively.

${ }^{143}$ Saner and Fasel (n 48) 284.

144 Krajewski (n 26) 359. This important fact of partial commitment (only private education) is lost on Tomasevski, who suggests wrongly that the EC has made full commitments in the area of education, cf. Tomasevski (n 31) 13.

145 Revised offer on services (20 April 2005)<http://trade-info.cec.eu.int/doclib/docs/2005/ april/tradoc_122676.pdf>

${ }^{146}$ Request in the service negotiations (25 January 2005) <http://trade-info.cec.eu.int/ doclib/docs/2005/january/tradoc_121197.pdf> (announcing, however, that "only the US would receive a request on higher education services but strictly limited to privately-funded education services"). One author has, however, argued that the request addressed to the US "has to be interpreted as a clever move to signal willingness to negotiate in the education field"; Scherrer (n 47) 502. 
from unlikely that the EC will start seeking commitments in these areas, in particular from developing countries as "compensation" for EC "sacrifices" in the field of agriculture. ${ }^{147}$

The contrast between internal case law and externally orientated rules regarding economic liberalisation vs. education provision has only increased with the CT. While Article III-145 CT sustains the precise wording of the current Article 50, first sentence EC on which the ECJ has based its case law, the provisions of the common commercial policy have, however, been changed as compared to the EC Treaty currently in force. The CT proposes far-reaching adaptations in the common commercial policy provisions, including with regard to education services. Article III315(4), para. 3, under (b) reads: "The Council shall ... act unanimously for the negotiation and conclusion of agreements ... in the field of trade in ... education ... services, where these agreements risk seriously disturbing the national organisation of such services and prejudicing the responsibility of Member States to deliver them..." ${ }^{148}$ The wording that only a "risk of seriously disturbing the national organisation of education services" will justify unanimity voting ${ }^{149}$ can be taken as signifying a political determination for future EC action on education services.

Article III-315(4), para. 3 was changed at the last minute from the version agreed upon within the European Convention. More particularly, initially it was also agreed that unanimity in concluding agreements regarding liberalisation of education services should be required. Krajewski has noted that since many members had repeatedly called for unanimity, the initial "Giscard" draft "represented the will of a large group, possibly even the majority of the Convention" that came to be overruled by the European Council. ${ }^{150}$ On the other hand, economic liberalisation of education provision is hardly a new item on the European agenda. The European Roundtable of Industrialists, a corporate lobby group, already declared in 1998 that "the provision of education is a market opportunity and should be treated as such". ${ }^{151}$

\subsection{A human rights perspective of internal and external EC activities in the economic liberalisation/education provision nexus}

Even the most superficial look will reveal that human rights have been given a more visible place in the CT. This is an open invitation to

\footnotetext{
147 Scherrer (n 47) 500.

148 Emphasis added.

${ }^{149}$ Emphasis added. The wording implies a fall-back to qualified majority voting (art III315(4) para 1) if "seriously disturbing" is not established.

150 M Krajewski, 'External Trade Law and the Constitution Treaty: Towards a Federal and More Democratic Common Commercial Policy?' (2005) 42 CMLRev 91, 121.

${ }^{151}$ Steketee (n 38) fn 152.
} 
assess whether a clearer human rights perspective can be articulated for the purpose of positioning oneself in the internal economic liberalisation/ education provision debate. The human rights now placed at the heart of the CT were substantively copied from the Charter of Fundamental Rights drafted in 2000. Also the "explanations" that were adopted in parallel to the Charter now appear in attachment to the CT (albeit at times in a slightly amended form) in the shape of a Declaration.

For the purpose of our discussion it is interesting to provide the wording of the provision on education in full, precisely because it has been described as a "slightly odd little pot pourri": ${ }^{152}$

\section{Article 14 EU Charter}

1. Everyone has the right to education and to have access to vocational and continuing training.

2. This right includes the possibility to receive free compulsory education...

3. The freedom to found educational establishments...

\section{Explanation to Article 14 Charter}

1. This Article is based on the common constitutional traditions of Member States and on Article 2 of the first Protocol to the ECHR....

It was considered useful to extend this article to access to vocational and continuing training... and to add the principle of free compulsory education. As it is worded, the latter principle merely implies that as regards compulsory education, each child has the possibility of attending an establishment which offers free education. It does not require all establishments which provide education or vocational and continuing training, in particular private ones, to be free of charge. Nor does it exclude certain specific forms of education having to be paid for, if the State takes measures to grant financial compensation. Insofar as the Charter applies to the Union, this means that in its training policies the Union must respect free compulsory education...

2. Freedom to found public or private educational establishments is guaranteed as one of the aspects of freedom to conduct a business but it is limited by respect for democratic principles and is exercised in accordance with the arrangements defined by national legislation.

A first observation is that, on comparison, the international human rights law provisions on education are much broader than the Charter's

${ }_{152}$ Wallace and Shaw (n 101) 223. 
wording. As was indicated in section 3, the principle of free compulsory education only implies that each child in compulsory (primary and secondary) education should have the right to attend a school free of charge. This wording can be taken to imply that under the Charter there is no right to the provision of higher and adult education free of charge. ${ }^{153}$ Moreover, the Charter does not include the requirement to progressively introduce free education in higher education. Therefore, it is narrower in scope than the ICESCR in terms of accessibility. ${ }^{154}$

Perhaps a more intriguing aspect of the explanations is the phrasing in the second paragraph that can be read as saying that also the freedom to found a public school is an aspect of the freedom to conduct a business. If this is meant to imply that running a public school can be seen as an "ordinary" economic activity, this can be viewed as at odds with the ECJ's public education provision case law discussed above.

In that light, it is worth restating from a wider international human rights viewpoint in what way education provision can be seen as especially important for a society. Complementary invocation of human rights may equip Member States seeking to resist economic law subjection with arguments based on these norms that have now gained additional standing in EC law. Tomasevski has summarised well the nature of the right to education:

[T] he right to education unlocks other rights when guaranteed, while its denial leads to compounded denials of other human rights ... The economic rationale for the right to education [has always been] - and remains - that investment in education should be made by the governments because it yields economic returns ... Moreover, education is not only, not even mainly, about the transmission of knowledge and skills ... Education is a public good because it represents the most widespread form of institutionalised socialisation of children. ${ }^{155}$

In that light, a state could argue on the basis of the Humbel formula that the protection of the human rights to education is a duty that it fulfils toward, and is bound to protect for, its population - and perhaps to the exclusion of too great a number of non-national economic agents and individuals.

More generally, it is of course understandable that arguments in justification/exemption by states may often look as if they are "reflexively conservative". ${ }^{156}$ Yet, it should not be forgotten that conservatism may equally be "conservationist" of a situation that is the fruit of past social

\footnotetext{
153 Ibid 235-236.

154 Ibid.

155 Tomasevski (n 31) 74.

${ }^{156}$ Davies (n 90) 28.
} 
progressiveness. The merit of invoking a need for conservation depends on the state of social development already reached and the attempts made to preserve it. While there is nothing sacred about a national cultural or social status quo, one should be extremely careful in approaching very complex matters defining the structure of a state and national society solely through the prism of economic liberty. If the fear is solely that an exclusionary and definite "definition of ... social services, or a distinction between economic and non-economic services based on goal or character rather than organisation would encourage states ... to portray ever-more activities as 'social' in order to benefit from the right to protectionism", ${ }^{157}$ human rights can perhaps be seen as an additional tool by the ECJ to assess the nature of the state's claim. The right to protectionism and the duty to protect its population (in the sense of Humbel) must go hand in hand.

The increased relevance that the CT seemingly attaches to human rights internally is also reflected in its wording concerning external action. Human rights protection is for the first time mentioned as an explicit aim of the EC's external action, and therefore for common commercial policy. This can be interpreted as having significant implications. As has been suggested, "while some of [the 'new' trade policy objectives, such as human rights] are currently contained ... in the Preamble of the EC treaty ... Article III-315(1) [second sentence] in conjunction with Article III-292(1) explicitly requires the common commercial policy to contribute to these objectives rather than simply focus on the reduction of barriers to trade". ${ }^{158}$

The question now arises whether the insights from a human rights viewpoint articulated for the internal EC situation with regard to the balance between economic liberalisation and protecting access to education for all can also be applied externally. In particular, in line with the human rights precautionary principle as suggested in the previous section, could human rights arguments based on the Charter or Article III-292 CT provide for useful a priori analysis to help states assess the conditions under which commitments can be sought in the field of education? Given the ambiguity of the terms of Article 14 Charter, however, it seems unlikely that it will be of great help in providing a coherent answer to this query.

In the light of the analysis in the previous and current section, caution is called for in moving toward the greater subjection of education provision to the logic and law of economic liberalisation. In the face of uncertainty about the effects of the economic liberalisation of education,

\footnotetext{
157 Ibid 45.

158 Krajewski (n 150) 107-108. Emphases added.
} 
careful national and EC trade policy-makers should not naturally rule out the possibility of (temporary) pre-emptive non-action as a legally and politically compelling legislative or negotiation option. Therefore, it seems essential for EC countries for the time being to hold their cards against their chest, not only in terms of offering commitments, but also in terms of seeking commitments - even if current conditions in world trade negotiations may suggest a reverse dynamic ${ }^{159}$ - to avoid implications that are hard to reverse for EU citizens and non-EU citizens alike.

\section{Conclusion}

This paper has studied the interplay of economic liberalisation and the provision of education both in the WTO and the EC context. On providing an analytical background to this discussion, it has become clear that steering a course between uncompromising trade liberalisation and unequivocal rejection of anything relating to economic liberalisation leads to largely undiscovered waters. To help give some guidance, the human rights law compass can be applied, as it offers a critical perspective to measure both claims based on trade, as well as those based on non-trade policies.

From the perspective of education policy-makers, integrating aspects of human rights law into a challenge to the WTO liberalisation of education services would likely both condition and bolster the case for pushing back market forces for the sake of a greater good. It could help articulate more precisely concerns about "giving education to the market", and make them more balanced to take account of the educational entitlement of all individuals on WTO Member States' territories. Such a more convincing combination of the right to education and education policy concerns would make it easier for developing states in particular to resist commitments in the field of education services. If it came to that, it would also make the challenge more legally precise, possibly enabling the WTO Dispute Settlement System to take on board educational concerns on their more precisely articulated terms if and when a WTO Member State were to present its defence in such terms.

In the EC setting, contradictory tendencies in current and possible future legal provisions with a bearing on the economic liberalisation of education provision make it very hard to draw a clear and unequivocal picture of the legal state and nature of the debate. The analysis has shown that tendencies seem to go in the direction of insulating the provision of education from economic law in the internal setting, while setting

159 Scherrer (n 47) 500 (warning against the fact that "Liberalisation in trade in services can now be wrung from developing countries with concessions on textile or agriculture imports for example".) 
the stage for adopting a more economic approach to the same issue in the common commercial policy. Also, the perspective of human rights law in the form of an analysis based on the Charter does leave an ambiguous picture. On the one hand, it hesitatingly acknowledges the obligation for primary and secondary education to be provided free of charge, but falling short of international norms. On the other hand, its explanations can be read as indirectly questioning the ECJ's case law on the exclusion of public education provision from the scrutiny of economic law. It will doubtless be the ECJ that will eventually need to give each of these elements a place if the CT eventually comes into force.

Finally, and more generally, it is possible to believe strongly in trade liberalisation, to subscribe to the importance of the provision of education, and to defend the imperative of human rights protection - all at the same time. Yet, as it has emerged in this paper, when trade and nontrade law clash, and human rights protection is added, difficult issues arise that are in fact largely still to be mapped. This paper has intended to illustrate what type of complex questions a Janus-faced trade/human rights lawyer confronts without giving in to the seduction of convenient selective blindness in two of his four eyes. In approach and substance, an attempt has been made to show that taking both trade/non-trade and human rights law seriously may lead legal analysts more conscientiously to start walking "sideways", keeping two eyes firmly on developments on the human rights landscape in front, and two eyes on the trade/nontrade landscapes in the back. "Blind" fundamentalism, or continued nonengaging advocacy on either side, is not likely to let us see a great deal of progress. That would be a great shame. For, after all, the god Janus also represents the transition from primitive life to civilisation ${ }^{160}$ (and, to my knowledge, he only possesses one brain).

160 Janus, Encyclopedia Mythica < http://www.pantheon.org/articles/j/janus.html>. 